\title{
Highly Sensitive Test-System for Diagnostics of Equine Herpes Virus Serotypes 1 and 4
}

\author{
Sadikaliyeva SO, Shorayeva KA*, Shynybekova GO, Onynbayev MB and Sultankulova KT \\ The Research Institute for Biological Safety Problems, Ministry of Education and Science of Republic of Kazakhstan, Kazakhstan
}

Submission: August 04, 2017; Published: August 21, 2017

*Corresponding author: Shorayeva KA, The Research Institute for Biological Safety Problems, Ministry of Education and Science of Republic of Kazakhstan, Science Committee, Gvardeiskiy, Kordaiskiy rayon, Zhambylskaya oblast, 080409, Republic of Kazakhstan, Email: K.A.Shorayeva@mail.ru

Abstract

In this paper presented the results of the development of a multiplex PCR test system. This test system allows to identify Equine herpesvirus serotypes 1 and 4 .

Keywords: Equine herpesvirus; Multiplex PCR; Serotypes 1 and 4; Test system

\section{Introduction}

For the laboratory diagnosis and identification of viral diseases of horses, various serological and immunological methods have been developed and are currently in use in the world. All of these methods have their diagnostic value - some of them require considerable time, others have low sensitivity and specificity. Therefore, the improvement and development of more sensitive and specific, as well as rapid methods of laboratory diagnosis remains an urgent problem to this day.

The method of PCR has become widespread in the diagnosis of viral diseases of horses. Despite some limitations, it is undoubtedly indispensable for early rapid diagnosis, in particular, diseases such as influenza, rinopneumonia, viral arteritis and number of other infections of horses [1].

In recent years, rinopneumonia has been diagnosed in a number of European countries, including in the CIS [2-5]. In Kazakhstan, there are pathogens of two immunologically independent types of infection: equine herpesvirus 1 (EHV-1) and equine herpesvirus 4 (EHV-4) serotypes, which are often associated with respiratory diseases of foals [3]. Proceeding from this, the purpose of this work is to develop a test system for the diagnosis of EHV-1 and EHV-4 using the multiplex PCR method. As a research object, bioassays were performed in the territory of the Republic of Kazakhstan with suspected EHV, and strains of Equidherpesvirus 4/KZ/2-15 and EHV-1/KZ/2015.

The search and selection of nucleotide sequences of segments of EHV are carried out in the international database of GenBank.
Analysis of the nucleotide sequences of genes or their individual fragments was carried out using various computer software packages, such as Vector NTISuite 9, DNASISMAX 1.0, BioEdit 7.0. Design of primers for PCR. The primers were designed using various computer programs, the main ones being Oligo 6 and Vector NTISuite 9. The isolation of the viral DNA was carried out by the CTAB buffer technique. To set up was used PCR, a set of "AccuPrime Taq DNA Polymerase", Invitrogen (USA).

As a result of the experiments, two pairs of the most optimal primers were selected for simultaneous diagnosis in multiplex PCR. Multiplex PCR was performed with simultaneous use of primers for 1 and 4 serotypes of EHV in the experimentally established concentrations under identical PCR conditions with the strains Equid herpesvirus 4/KZ/2-15 and EHV1/KZ/2015. As a result, specific PCR products were produced - DNA fragments with a size of $\sim 500 \mathrm{bp}$ and $\sim 240 \mathrm{bp}$, respectively for EHV-1 and EHV-4.

The developed multiplex PCR test system for DNA detection of EHV-1 and EHV-4 was tested on strains stored in the NIIPBB microorganism museum and pathological materials. Specific products were produced only in those samples that contained DNA of EHV-1 and EHV-4.

Summarizing the obtained data, it can be concluded that as a result of the conducted studies, for the first time in the Republic of Kazakhstan, a multiplex PCR test system was developed that makes it possible to identify EHV-1 and EHV-4 simultaneously in the samples under study. 
The PCR test system for the diagnosis of EHV-1 and EHV-4 can be used to screen a large number of samples for the detection of EHV. Moreover, in comparison with classical methods, the analysis time is reduced by dozens of times and allows analysis directly in small veterinary laboratories, avoiding the transport of samples.

\section{References}

1. www.oie.int

2. OIE-World organization for animal health. World Animal Health Information Database (WAHID) Interface.
3. Patel JR, Heldens J (2005) Equine herpesviruses 1 (EHV-1)and 4 (EHV4) epidemiology, disease and immunoprophylaxis: a brief review. Vet J 170(1): 14-23.

4. Taouji S, Collobert C, Gicquel B, Sailleau C, Brisseau N, et al. (2002) Detection and isolation of equine herpesviruses 1 and 4 from horses in Normandy: an autopsy study of tissue distribution in relation to vaccination status. J Vet Med B Infect Dis Vet Public Health 49(8): 394399.

5. Gur S, Yapici O (2008) Equine Herpesvirus type 1 and 4 in Individually Reared Horses in Central and Western. Acta Vet Brno 77: 609-613.

Your next submission with Juniper Publishers
will reach you the below assets
- Quality Editorial service
- Swift Peer Review
- Reprints availability
- E-prints Service
- Manuscript Podcast for convenient understanding
- Global attainment for your research
- Manuscript accessibility in different formats
( Pdf, E-pub, Full Text, Audio)
- Unceasing customer service
Track the below URL for one-step submission
https://juniperpublishers.com/online-submission.php

